\title{
Do Amish One-Room Schools Make the Grade? The Dubious Data of Wisconsin v Yoder
}

\author{
William A. Fischel†
}

\section{INTRODUCTION}

American public school districts declined in number from about 200,000 at the beginning of the twentieth century to fewer than 15,000 in 2010.' Almost all of this decline was the result of consolidation of rural one-room schools, which were usually the only schools in their districts, into large-area districts. ${ }^{2}$ This movement is regarded by education historians as the product of a top-down political process in which local interests were steamrollered by state officials and the professional educational establishment. ${ }^{3}$ Implicit in this account is the idea that the one-room schools were doing a good job, except for being imperfectly bureaucratized.

My view of this transformation is different. ${ }^{4}$ The great majority of the consolidations had to be voted on by the residents of the districts involved or their locally elected representatives. Many districts refused for years to consolidate. ${ }^{5}$ The chief advantage of district consolidation was that it allowed rural and small-town children to be streamed from multiroom, age-graded elementary schools into high schools. The one-

$\dagger$ Professor of Economics and Robert C. 1925 and Hilda Hardy Professor of Legal Studies, Dartmouth College.

For helpful comments and advice, I thank Liz Cascio, Robert Costrell, Nora Gordon, Trudy Huntington, Karen Johnson-Weiner, Donald Kraybill, David McConnell, Steven Nolt, Shawn Peters, Lawrence Rosen, Bruce Sacerdote, and David Weaver-Zercher. Their generosity should not be taken as an indication that they agree with my analysis and conclusions.

1 See William A. Fischel, Neither "Creatures of the State" nor "Accidents of Geography": The Creation of American Public School Districts in the Twentieth Century, $77 \mathrm{U}$ Chi L Rev 177, 177 (2010); Department of Education, Digest of Education Statistics (National Center for Education Statistics Nov 2010), online at http://nces.ed.gov/programs/digest/d10/tables /dt10_090.asp (visited Oct 23, 2011).

2 See William A. Fischel, Making the Grade: The Economic Evolution of American School Districts 68-69 (Chicago 2009).

3 See, for example, David Tyack and Thomas James, State Government and American Public Education: Exploring the "Primeval Forest," 26 Hist Educ Q 39, 66-67 (1986).

4 See Fischel, Making the Grade at 101 (cited in note 2). See also Fischel, 77 U Chi L Rev at 177 (cited in note 1).

5 See Fischel, 77 U Chi L Rev at 192-95 (cited in note 1). 
room school was well suited for spreading basic literacy and numeracy across the continent, but it was inadequate for preparing students for high school in the twentieth century. ${ }^{6}$

A way of testing my account is to look at the most persistent exceptions to the abandonment of one-room schools. The Amish are a Protestant sect whose members employ much of the agricultural and household technology of the nineteenth century.' As American rural school consolidation reached the Amish (circa 1930-1960), most of them left the public school system and re-created the oneroom schools that were the dominant mode of American education in the nineteenth century. ${ }^{8}$

The great virtue of the one-room school was (and still is, for the Amish) the sense of local communal participation that it engendered. ' What is more controversial is the claim that the Amish oneroom school is, with the possible exception of science education, the equivalent of eight grades in a modern school..$^{10}$ If this is the case, American education took an enormously expensive, socially disruptive wrong turn about a century ago.

The persistence of the Amish one-room schools and their endorsement by the US Supreme Court in Wisconsin v Yoder ${ }^{11}$ seem to support that idea. The Court held that the Free Exercise Clause of the First Amendment prevented the state from requiring Amish parents to send their children to school beyond the eighth grade. ${ }^{12}$ Although exemption from high school was its most important effect, Yoder also endorsed the nonstandard elementary education offered in Amish one-room schools, noting that "Amish children in the eighth grade achieved comparably to non-Amish children in the basic skills." I I will show that the study on which this claim is based is badly flawed. One-room schools may serve the Amish well enoughthis Article does not recommend that the Amish be forced back into

See id at $185-86$.

7 The Amish come in a variety of sects, of which the Old Order are the most numerous and best known. See Charles E. Hurst and David L. McConnell, An Amish Paradox: Diversity \& Change in the World's Largest Amish Community 18, 35-36 \& table 2.1 (Johns Hopkins 2010).

8 See Karen M. Johnson-Weiner, Train Up a Child: Old Order Amish \& Mennonite Schools 7 (Johns Hopkins 2007).

9 See Wayne E. Fuller, The Old Country School: The Story of Rural Education in the Middle West 45 (Chicago 1982); John A. Hostetler and Gertrude Enders Huntington, Children in Amish Society: Socialization and Community Education 109 (Holt, Rinehart, and Winston 1971).

10 See Hostetler and Huntington, Children in Amish Society at 96 (cited in note 9).

11406 US 205 (1972).

12 Id at $230-31$.

13 Id at 225-26 \& $n$ 13. 
the standard school system-but that is because they do not want access to secondary education that most other Americans wanted.

\section{THE AMISH ARE UNROMANTIC COMMUNITARIANS}

The Amish live almost exclusively in rural areas of the United States, with a majority in Pennsylvania, Ohio, and Indiana. ${ }^{14}$ Their traditional clothing and lifestyle, especially their horse-and-buggy transportation, remind many of rural America in the nineteenth century. The defining aspect of Amish farming and transportation is the use of the horse rather than the tractor or the automobile. Some Amish farms will use some gas-powered machinery for harvesting grain and other field work, but the machines are usually drawn by horses. Their homes are not wired for external power or communications. They forswear radios, in-house telephones, televisions, and computers.

Most Amish live on farmsteads, and a sizable percentage still derive most of their income from agriculture. Farming is, however, a declining occupation. Their large families-six or more children are common-have outstripped the supply of land in their traditional settlements, and declining commodities prices make it more difficult for those who do have farms to make even the modest income that satisfies Amish goals. ${ }^{15}$ As a result, a majority of Amish are now engaged in small enterprises or are employed as relatively unskilled workers in rural and small-town businesses owned by both Amish and non-Amish employers. ${ }^{16}$ However, all Amish continue to keep modern technology at a wary distance within and around their rural homes.

The Amish use antiquated technology in their homes and farms because of the pervasiveness of religion in their lives. ${ }^{17}$ The Amish are "Anabaptists," a term that seems to suggest they are against baptism but really means they perform only adult baptism. ${ }^{18}$ In the German-speaking regions of Europe where they originated, they and other Anabaptists were severely persecuted for this seemingly minor variation in Christian practice and for their steadfast refusal to serve in the military or otherwise use violence to defend themselves or

\footnotetext{
14 John A. Hostetler, Amish Society 98 table 2 (Johns Hopkins 4th ed 1993).

15 See Hurst and McConnell, Amish Paradox at 196 (cited in note 7).

16 See id at 197-200.

17 See Donald B. Kraybill, The Riddle of Amish Culture 36 (Johns Hopkins revd ed 2001).

18 Hurst and McConnell, Amish Paradox at 14 (cited in note 7).
} 
their property. ${ }^{19}$ They emigrated to Pennsylvania in the eighteenth and nineteenth centuries and soon spread westward. ${ }^{20}$

Among the Amish, adult baptism must be freely chosen by both men and women, and the choice is usually made in their late teens. ${ }^{21}$ Baptism is not just a covenant between the deity and the person who chooses it. Those who accept baptism agree to submit to the congregation's ordinances and understandings that are collectively known as the Ordnung. ${ }^{22}$ These largely unwritten rules are interpreted by their unpaid, locally selected clergy. ${ }^{23}$

The Ordnung dictates that Amish may not own automobiles but may ride in vehicles operated by non-Amish drivers. The types of nonfarm jobs and businesses that Amish may engage in are likewise subject to collective control. ${ }^{24}$ All Ordnungs permit trade with the rest of the world for a limited variety of consumer and investment goods. Amish clothing and furnishings are "plain and simple" but not entirely homemade. ${ }^{25}$ It is not uncommon to see a van (owned and piloted by a non-Amish driver) parked at a Walmart being loaded with staples purchased by a large Amish family or two. ${ }^{26}$

The Amish are more suspicious of government than of modern business. They will not serve on juries and rarely initiate lawsuits, which they regard as coercive. ${ }^{27}$ Their Ordnungs disallow acceptance of government transfers such as Social Security. ${ }^{2 x}$ Instead, the Amish provide their own informal transfer systems for the aged, sick, and needy of their community. Most important for the present article, their Ordnungs determine that Amish children must not attend a formal high school, even it if were operated by coreligionists. ${ }^{24}$

Amish theology enjoins them to be "not of this world." Otherworldliness does not mean monastic spirituality. The Amish

19 Id at $14-15$.

20 Steven M. Nolt, A History of the Amish 63, 75, 118-19 (Good Books revd ed 2004).

The Amish are extinct in Europe.

21 See Kraybill, Riddle of Amish Culture at 117 (cited in note 17).

22 See id at 112-13, 117-19.

23 See Hurst and McConnell, Amish Paradox at 16 (cited in note 7).

24 See Kraybill, Riddle of Amish Culture at 115 (cited in note 17).

25 Id at 60.

26 See Thomas J. Meyers and Steven M. Nolt, An Amish Patchwork: Indiana's Old Orders in the Modern World 1-2 (Indiana 2005).

27 Kraybill, Riddle of Amish Culture at 31 (cited in note 17).

28 See id at 277-78. The Amish were granted exemptions from Social Security and Medicare taxes, but they pay all other taxes. Id at 278-79.

29 See Mark W. Dewalt, Amish Education in the United States and Canada 20 (Rowman \& Littlefield 2006).

30 Hostetler, Amish Society at 76 (cited in note 14). 
are remarkably communitarian and equalitarian among themselves. ${ }^{31}$ But they do not attempt to convert others to their religion, and they discourage "English" seekers of a simpler life who would like to join them. (The Amish speak Pennsylvania German among themselves.) ${ }^{32}$ Without converts, the Amish grow only by natural increase, and they have done so quite successfully. ${ }^{33}$ The limit on their numbers is primarily defection by young adults to other religions, most commonly their more worldly and geographically proximate Anabaptist cousins, the Mennonites. ${ }^{34}$ Defection rates declined in the latter part of the twentieth century, and about 85 percent of the children of Old Order Amish have remained in the fold as adults. ${ }^{35}$ As a result, estimates of Amish population, which had dwindled to about 5,000 in 1900 , have grown from about 50,000 in 1970 to nearly 250,000 in $2010 .^{36}$

\section{ONE-ROOM SCHOOLS HELP SOLVE AN AMISH ECONOMIC PROBLEM}

The Amish seem to be the antithesis of "homo economicus" in that they abjure most of the pleasures of a modern economy and aspire to a religiously derived communal spirit that disapproves of individualism, competition, and personal ambition. ${ }^{37}$ (In these respects, they seem rather different from the Jeffersonian "sturdy yeoman," to whom they were compared by the chief justice in Yoder.) ${ }^{38}$ Called "Gelassenheit," this communal spirit would seem beyond economic analysis. ${ }^{39}$ But economics is the science of scarce means, not about particular ends. Their old-fashioned ways are an important means of maintaining Amish religious identity.

\footnotetext{
31 See Kraybill, Riddle of Amish Culture at 29-30 (cited in note 17).

32 Id at 55.

33 See id at 335 app B.

34 See Hostetler, Amish Society at 303 (cited in note 14); Albert N. Keim, From Erlanbach to New Glarus, in Albert N. Keim, ed, Compulsory Education and the Amish: The Right Not to Be Modern 9-10 (Beacon 1975).

35 See Hurst and McConnell, Amish Paradox at 80 table 3.1 (cited in note 7).

36 Donald B. Kraybill, Introduction: The Struggle to Be Separate, in Donald B. Kraybill and Marc A. Olshan, eds, The Amish Struggle with Modernity 1, 9 table 1.1 (New England 1994); Young Center for Anabaptist and Pietist Studies, Amish Population Trends 1991-2010: Twenty-Year Highlights (Elizabethtown College 2011), online at http:/www2.etown.edu /amishstudies/Population_Trends_1991_2010.asp (visited Oct 24, 2011).

37 See Kraybill, Riddle of Amish Culture at 29-30 (cited in note 17).

38406 US at 225-26 \& n 14.

39 See Kraybill, Riddle of Amish Culture at 29-30 (cited in note 17) ("Roughly translated, Gelassenheit means 'submitting, yielding to a higher authority.'").
} 
Old-fashionedness is not a static ideal. Twenty-first century Old Order Amish often travel as passengers in cars, buses, and trains. In their business affairs, many use telephones located outside their homes and, increasingly, cell phones. ${ }^{40}$ The Amish accept modern medical care, which they pay for out of pocket or with the aid of fellow congregants. ${ }^{41}$ Despite such accommodations, the Amish maintain enough of their old-fashioned ways to keep the rest of the world at a polite distance.

But the polite distance creates a problem for their youth. Without converts, the Amish must preserve their way of life and religion by transferring it to their children and keeping them in the fold. ${ }^{42}$ They tend to live in contiguous settlements of several congregations, but the personal freedom and consumption opportunities of their non-Amish neighbors, tourists, customers, and business associates are frequently evident to them and their children. ${ }^{43}$

The Amish maintain their adult cohesiveness by means of rewards and penalties. The benefits of conformity are a comprehensive system of spiritual and social support and a slowly evolving acceptance of modern conveniences and sources of income. Although the Amish are committed to hard work and simplicity, most are not unusually ascetic. They visit one another to gossip, eat heartily, hold quilting bees, hunt and fish, tell jokes, and play softball. ${ }^{4}$ They read the tamer works of American literature and sometimes travel in groups to national parks. ${ }^{45}$ Controlled adoption of modern technology and consumer goods probably helps to hold families within the Amish fold. But leaders are also aware that allowing too much modernity has caused defections by families from liberalized Amish congregations to more conservative groups ${ }^{46}$

The penalty for baptized adults who stray from the strictures of the Ordnung is "shunning," a systematic isolation from the community, including from members of his or her own family. ${ }^{47}$ Raised in a community in which communal bonds, egalitarian sociability, and a collective road to salvation are paramount, Amish who are shunned endure a steep price that is mitigated primarily by

\footnotetext{
40 Hurst and McConnell, Amish Paradox at 52 (cited in note 7).

41 See id at 227-34.

42 See Kraybill, Riddle of Amish Culture at 317 (cited in note 17).

43 See id at 309-11, 324.

44 See id at 150-52.

45 See id at 153.

46 See Hurst and McConnell, Amish Paradox at 51-52 (cited in note 7).

47 See id at 83-84.
} 
the congregation's willingness to forgive those who publicly repent of their transgressions and return to the fold..$^{48}$ (The Mennonites, who usually do not shun defectors, could be thought of as having to increase the economic benefits to members-modern consumption opportunities - since the costs of religious disobedience are lower.)

Full-scale shunning is applied only to adults who have accepted baptism and then persistently strayed from the local Ordnung. ${ }^{49}$ At age sixteen - a year or two after their terminal year in school (eighth grade) but before baptism - Amish boys and girls are given leave to experience the non-Amish world. They can, to an extent that varies locally, drive cars, wear contemporary clothes, use modern technology, and socialize with non-Amish peers. ${ }^{50}$ This period of Rumspringa ("running around") is normally followed by a decision by Amish in their late teens or early twenties to accept baptism and the strictures of the Ordnung. ${ }^{\text {st }}$

The idea behind Rumspringa is that acceptance of baptism is more sincere if one has experienced the world outside first. ${ }^{52}$ But in fact most Amish youth are unprepared to use this time for anything more than bonding with their Amish peers and some slightly naughty recreation..$^{53}$ On the order of 90 percent eventually accept baptism, embrace church obligations, and, sooner or later, marry an Amish man or woman..$^{54}$

Amish youths' lack of preparation for meaningful engagement with the outside world during Rumspringa is in large measure the product of the limitations imposed on Amish youth by their oneroom schools. The Amish know from experience that formal high school education is extremely hazardous to Amishness. Both the Amish and the anthropologists who have studied them agree that mainstream, advanced education would open up worldly possibilities, and association with non-Amish students would

\footnotetext{
48 See Kraybill, Riddle of Amish Culture at 139 (cited in note 17).

49 See Hurst and McConnell, Amish Paradox at 83 (cited in note 7).

so See Kraybill, Riddle of Amish Culture at 145 (cited in note 17).

51 Id at $145-47$.

52 Hurst and McConnell, Amish Paradox at 68 (cited in note 7).

53 See Steven V. Mazie, Consenting Adults? Amish Rumspringa and the Quandary of Exit in Liberalism, 3 Persp Polit 745, 752-53 (2005) (stating that many youth do not explore the outside world they have yet to be exposed to but rather socialize at bowling alleys or get drunk in cornfields); Kraybill, Riddle of Amish Culture at 145-46 (cited in note 17) (describing the range of activities young people engage in with their peers, from recreational sports to parties with alcohol).

54 See Kraybill, Riddle of Amish Culture at 186 (cited in note 17). See also Mazie, 3 Persp Polit at 752-53 (cited in note 53).
} 
undermine their commitment to the Amish way of life and pave the way out. ${ }^{\text {ss }}$

\section{ONE-ROOM SCHOOLS WORKED BEST FOR A LIMITED CURRICULUM}

Public schools were formerly an exception to Amish disengagement with government institutions. Before World War II, most Amish attended the same one-room schools that their nonAmish neighbors attended. ${ }^{56}$ The Amish would end their education with the eighth grade. Their engagement with public schools unraveled when rural school districts were consolidated and the minimum school-leaving age was raised from fourteen to sixteen." After a period of nonviolent resistance to truancy laws, the Amish in most states were granted exceptions. ${ }^{58}$ Their children did not have to complete more than eight years of formal education, and the Amish could establish their own parochial schools with Amish-approved teachers. In Pennsylvania, Ohio, and Indiana, where the majority of the Amish reside, a program of home-based vocational education was required for another two years, but most of this involved homebased training that Amish teenagers would have received without state compulsion. ${ }^{59}$

Amish one-room schools bear more than a passing similarity to their nineteenth-century predecessors. Schools in both eras were neighborhood based, and children usually walked to school. As in the early nineteenth century, the operational expenses of Amish schools are largely funded by parental tuition assessments. ${ }^{60}$ Amish one-room schools are modest affairs, and their comforts largely

55 See Hostetler and Huntington, Children in Amish Society at 102 (cited in note 9); Wayne Edgar Miller, A Study of Amish Academic Achievement *3-5 (unpublished PhD dissertation, University of Michigan, 1969) (on file at the University of Michigan); Kraybill, Riddle of Amish Culture at 176 (cited in note 17); Sara E. Fisher and Rachel K. Stahl, The Amish School 88 (Good Books revd ed 1997) (describing a former Amish man who attended high school and whose "sorrowful conclusion was that it is not possible for most Amish children to go to high school and remain Amish").

56 See Keim, From Erlanbach to New Glarus at 11 (cited in note 34).

57 Id at 13-15.

58 See, for example, Kan Stat Ann § 72-1111(g). See also Shawn F. Peters, The Yoder Case: Religious Freedom, Education, and Parental Rights $43-47$ (Kansas 2003).

59 See Dewalt, Amish Education at 88-89 (cited in note 29) (describing a Pennsylvania home-based vocational plan).

60 See Nancy Beadie, Tuition Funding for Common Schools: Education Markets and Market Regulation in Rural New York, 1815-1850, 32 Soc Sci Hist 107, 115 (2008); JohnsonWeiner, Train Up a Child at 154 (cited in note 8); Fuller, Old Country School at 26 (cited in note 9). 
reflect local home conditions. Outdoor toilets are the rule in areas settled by the more traditional groups. ${ }^{61}$

Teachers in early American one-room schools seldom had more education than their most advanced students. ${ }^{62}$ Amish teachers, who are almost always Amish themselves, are likewise lacking in formal education beyond the eighth grade. ${ }^{63}$ Local Amish school directors, who are typically parents of those in the school, do the hiring and pay the teacher. ${ }^{64}$ Most Amish teachers are unmarried young women who will stop teaching after their wedding, as was generally the case in early one-room American schools. ${ }^{\text {.5 }}$ The pay scale reflects the opportunity cost of teaching, which for unmarried Amish women is relatively unskilled labor as a household worker. ${ }^{66}$ However, eighth grade is a ceiling on the education of Amish teachers, so they should not be thought of as dysfunctional dropouts, and those who choose to teach get some assistance from Amish newsletters and training seminars. ${ }^{67}$

The method of instruction in nineteenth-century rural schools was to divide students into recitation groups according to previous accomplishment in each subject. ${ }^{*}$ Because attendance by many children was irregular, a recitation group in intermediate reading (say) could include children who were ages nine, eleven, thirteen, and sixteen. Recitation group members would be assigned a passage to read and (usually) memorize. Another group might be assigned something in arithmetic and another in spelling. They would study silently while the teacher examined another group in a subject they had previously been assigned to study. ${ }^{69}$

Groups would thus rotate between what we would now call study hall and the recitation bench and back again throughout the day. ${ }^{71}$ A teacher who taught four subjects at three levels each would thus have twelve recitation groups per day. Over a six-hour school

61 See Johnson-Weiner, Train Up a Child at 26-28 (cited in note 8).

62 See Carl F. Kaestle, Pillars of the Republic: Common Schools and American Society 1780-1860 20 (Hill \& Wang 1983).

63 Dewalt, Amish Education at 116 (cited in note 29).

64 Id at 54.

65 See id at 117; Kaestle, Pillars of the Republic at 20 (cited in note 62).

66 See Hostetler and Huntington, Children in Amish Society at 56 (cited in note 9).

67 See Dewalt, Amish Education at 121-24 (cited in note 29).

68 See David L. Angus, Jeffrey E. Mirel, and Maris A. Vinovskis, Historical Development of Age Stratification in Schooling, 90 Teachers Coll Rec 211, 216 (1988). See also Larry Cuban, How Teachers Taught: Constancy and Change in American Classrooms 1890-1980 25-27, 31 (Longman 1984).

69 See Cuban, How Teachers Taught at 19 (cited in note 68).

70 See id. 
day, each student's group would on average recite for half an hour in each subject, and each student would have the teacher's attention (in the student's recitation group) for a total of two hours and be in study hall four hours a day.

In Making the Grade, I argued that the recitation method was effective for teaching basic literacy and numeracy for a population that was highly mobile and widely dispersed, and whose children often could attend only part time." Children who missed a few weeks of a school term could return and join another recitation group and pick up where they left off. There was no need to start over in the same grade and waste time learning things already mastered, as there were no age-specific grades or even a standard school year. ${ }^{72} \mathrm{~A}$ "common school education" was complete when the scholar ran out of textbook material to learn. ${ }^{33}$

The problem with the ungraded method was that only a few subjects could be covered during each school day. With the rise of high school and its increased economic payoff around the beginning of the twentieth century, ${ }^{74}$ most urban schools shifted to the nowstandard age-graded method. This allowed a single teacher to teach several subjects to the same age-defined cohort of children. If she taught six subjects to the entire class who were all the same age, each subject would get one hour in the six-hour day, and students would not have to be in "study hall" except when in-class seatwork was part of the lesson plan.

The age-graded system was less viable in rural, one-room schools. A teacher with a full eight grades and six subjects to teach would have forty-eight separate recitation periods. This amounts to seven-and-a-half minutes per recitation period, or for the typical student, forty-five minutes of face time with the teacher (shared with his or her recitation group compatriots) over a six-hour day. Of course few of the one-room schools that tried to cover more than reading, spelling, and arithmetic literally followed such a schedule. ${ }^{75}$ But even with trimming the curriculum and combining classes, rural teachers often had more than two dozen daily recitations, averaging less than fifteen minutes. ${ }^{76}$ These educational disabilities finally made

\footnotetext{
71 Fischel, Making the Grade at 65 (cited in note 2).

See id at 123-24.

See id at $43-44$.

74 See Claudia Goldin and Lawrence F. Katz, The Race between Education and Technology 167 (Belknap 2008).

75 See Fischel, Making the Grade at 83-84 (cited in note 2).

76 See, for example, Cuban, How Teachers Taught at 119 (cited in note 68).
} 
rural voters accede to the consolidations that state-level educators had been urging for over a century.

Modern Amish one-room schools do not have the problem of spotty attendance that complicated age grading in earlier one-room schools." But dividing students into eight grade levels still runs into the inescapable problem of limited time. The modern Amish oneroom school has responded to the time constraints by teaching fewer subjects. The Amish do not believe in evolution, but they do not make a big deal about it because they teach very little science. History, social studies, art, and music are likewise given short shrift. Detailed accounts of Amish school days indicate that almost threequarters of each day is spent on reading, spelling, and arithmetic. ${ }^{78}$

\section{The YodeR Decision WAS Shaped By JOHN A. HoSTETlER}

By the 1960s, the Amish retreat from public education was well under way, but many state and local officials were initially unwilling to accept their nonstandard elementary schools. Amish parents were sometimes jailed for refusing to send their children to either public or private high school. ${ }^{79}$ In an especially heavy-handed incident, Iowa school officials attempted in 1965 to force Amish children in a oneroom school onto a bus to transport them to a public elementary school. ${ }^{80}$ Nationally circulated photographs of terrified, straw-hatted children running into cornfields to avoid what looked to many like a public kidnapping helped turn public opinion in favor of the Amish. ${ }^{81}$ Iowa's governor was forced to intervene and craft a compromise similar to that of other states that allowed the Amish to keep their one-room schools and avoid high school. ${ }^{82}$

Faced with unyielding, nonviolent resistance by an unthreatening people, most state legislatures let the Amish pursue their separate, traditional path. ${ }^{83}$ The event that displaced the negotiated education arrangements with individual states was the refusal of the Amish in a Wisconsin community to send their children to a state-approved high school. Wisconsin had not worked out any accommodation with the Amish - their presence in the state dated only from the 1960 s-and in 1968 local public school

77 See Dewalt, Amish Education at 54 (cited in note 29).

78 See, for example, id at 107, 114; Fisher and Stahl, Amish School at 32-39 (cited in note 55).

79 See Kraybill, Riddle of Amish Culture at 168-69 (cited in note 17).

80 See Hostetler and Huntington, Children in Amish Society at 97-98 (cited in note 9).

81 Hostetler, Amish Society at 264-65 (cited in note 14).

82 Id at 267-68.

83 See Peters, Yoder Case at $44-47$ (cited in note 58). 
authorities brought their truancy to the attention of state authorities. ${ }^{84}$ The Amish themselves were, for religious reasons, unwilling to hire an attorney. A non-Amish organization founded by a Lutheran minister persuaded Jonas Yoder and two other fathers to accept a legal defense. ${ }^{85}$ The judge in the trial court nonetheless held for the state of Wisconsin and fined the Amish parents token amounts for their noncompliance. The decision was appealed to the state supreme court. ${ }^{86}$

Unlike other state courts with similar cases, the supreme court of Wisconsin ruled in favor of the Amish. ${ }^{87}$ Because this was contrary to other states' rulings based on the First Amendment's Free Exercise Clause, the state attorney general appealed the decision to the US Supreme Court. The Court granted certiorari and in a unanimous decision (with a partial dissent by Justice William Douglas about the unexamined educational rights of the children) held that the Amish parents did not have to send their children to high school and could maintain their own elementary schools, subject to unspecified state regulations. ${ }^{88}$

The organization that represented the Amish at trial and through its appeals had as its star witness John Andrew Hostetler, who is widely regarded as the father of modern Amish studies. ${ }^{89}$ Born in 1918 to an Amish family, Hostetler declined Amish baptism and instead became a Mennonite. ${ }^{0}$ After conscientious-objector service in World War II, he attended a Mennonite college and earned a PhD in sociology from Pennsylvania State University in 1953. ${ }^{91} \mathrm{He}$ enjoyed a long and prolific career writing about the Amish and other Anabaptist societies until his death in 2001. His Amish Society became the leading academic treatise on the subject, going through four editions starting in 1963, and he wrote numerous popular books and articles on the Amish. ${ }^{2}$ Because he had declined baptism and thus not broken his vows in leaving the Amish, he was not shunned

84 See id at 7, 33-35.

85 See William C. Lindholm, The National Committee for Amish Religious Freedom, in Donald B. Kraybill, ed, The Amish and the State 109, 109-15 (Johns Hopkins 2d ed 2003).

86 Yoder, 406 US at 208-09.

87 State $v$ Yoder, 182 NW2d 539, 542 (Wis 1971).

88 Yoder, 406 US at 234-35.

89 David L. Weaver-Zercher, An Uneasy Calling: John A. Hostetler and the Work of Cultural Mediation, in David Weaver-Zercher, ed, Writing the Amish: The Worlds of John A. Hostetler 98, 100-01 (Pennsylvania State 2005).

90 See id at 101-04.

91 John A. Hostetler, An Amish Beginning, in Weaver-Zercher, ed, Writing the Amish 5, 25,29 (cited in note 89).

92 See Weaver-Zercher, Uneasy Calling at 111-15 (cited in note 89). 
as an apostate, and his fluency in Pennsylvania German helped him gain the confidence of his subjects. Hostetler, by the 1960s, was a professor of sociology at Temple University in Philadelphia, but his sympathies for the Amish were well-known among his colleagues and the Amish themselves.

Hostetler's testimony at the Wisconsin trial was enormously influential in the appellate decisions. ${ }^{24} \mathrm{He}$ explained the connection between the Amish insistence on a limited education and the survival of their religion. Requiring Amish children to go to high school or mix with non-Amish children in modern, regional elementary schools would lead them astray. Moreover, a study Hostetler had done assured the court that the eight years of education in one-room schools would be just as good as that in public schools. The study was noted in Chief Justice Warren Burger's opinion:

All of the children involved in this case are graduates of the eighth grade. In the county court, the defense introduced a study by Dr. Hostetler indicating that Amish children in the eighth grade achieved comparably to non-Amish children in the basic skills.

Hostetler and Huntington summarized a study that Hostetler had undertaken in 1969 with a grant from the US Office of Education. ${ }^{95}$ The achievement results referred to by the Court were only part of Hostetler's extensive report. The achievement tests and the statistical analysis were conducted by Wayne Edgar Miller, who used the results as the centerpiece of his $\mathrm{PhD}$ dissertation in education administration at the University of Michigan. ${ }^{96}$ Miller and Hostetler reported the same statistical study, but because each offered some different perspectives, I discuss both of them below but treat Hostetler as the principal investigator.

\section{THE HostetLer-Miller STUdy WAS MARRED BY SELECTION BIAS}

Hostetler's 1969 Office of Education project was an exercise in persuasion. While there was a gloss of objectivity-much of the

\footnotetext{
93 See id at 99, 132-33.

94 See Peters, Yoder Case at 90-94 (cited in note 58); Lawrence Rosen, The Anthropologist as Expert Witness, 79 Am Anthro 555, 563 (1977).

95 John A. Hostetler, Educational Achievement and Life Styles in a Traditional Society, the Old Order Amish ii (Department of Health, Education, and Welfare Sept 1969).

96 See generally Miller, Amish Academic Achievement (cited in note 55). Miller, like Hostetler, admired the Amish and spoke Pennsylvania German. Id at 2.
} 
background work reprises his scholarly Amish Society - the thrust of the report reads as a defense of the Amish way of life and their oneroom school system, as Hostetler had intended from the outset. ${ }^{\text {n }}$ On the basis of Miller's statistical study, Hostetler and Huntington, the source cited by the Supreme Court in Yoder, concluded, "As judged by education testing standards the overall performance of the Amish is similar to that of a representative sample of rural school children in the United States." ${ }^{98}$

Hostetler and Miller selected (with the help of Gertrude Huntington) fourteen private Amish one-room schools. ${ }^{99}$ The test that was the basis for Hostetler's comparative claims was a customized version of the Iowa Test of Basic Skills. ${ }^{100}$ The scores of the fourteen one-room schools were collectively compared to the same tests administered to both Amish and non-Amish children in six consolidated public schools in which students were divided by age cohorts-that is, they were multiroom schools with a teacher for each age-graded cohort. The Amish private schools included six from northern Indiana, seven from Ohio, and one from Ontario. The six public schools were in Ohio and Michigan..$^{101}$

Because the one-room schools were private, the researchers had to persuade Amish school directors, teachers, and parents to allow them to conduct the tests. The Amish were suspicious of tests that might be used against their system. So the authors explained that the purpose of their tests was to help the Amish and that the schools would not be identified by name or specific location. Even with these assurances, many schools declined."1' Hostetler admitted, "The possibility of obtaining a random sampling of all Amish children for testing was impossible and impractical." "w

Those that did agree to be tested were indeed special. Summarizing the study, Hostetler and Huntington explained, "The teachers were experienced, having taught no less than three years; they were considered by the community to be good teachers." Thus the Amish one-room schools were selected in a way that filtered out

97 See John A. Hostetler, Old Order Amish Child Rearing and Schooling Practices: $A$ Summary Report (1970), in Weaver-Zercher, ed, Writing the Amish 236, 236-37 (cited in note 89) (admitting that he only compared Amish educational achievement to their own community standards).

98 Hostetler and Huntington, Children in Amish Society at 96 (cited in note 9).

99 Hostetler, Educational Achievement at 51 (cited in note 95).

100 See note 109 and accompanying text.

101 Miller, Amish Academic Achievement at 116 (cited in note 55).

102 Id at $108-09$.

103 Hostetler, Educational Achievement at 50 (cited in note 95).

104 Hostetler and Huntington, Children in Amish Society at 90 (cited in note 9). 
inexperienced and ineffective teachers. (Cooperation of officials in the six public schools to which the Amish schools were compared was easily obtained, though they too were unidentified.) $)^{165}$

The problems of getting the Amish to cooperate did not end with getting the consent of adults. The children in the Amish schools were unfamiliar with testing. Miller indicated that the test administrators (who seem to have included himself) explained the tests carefully "with additional time provided to enable students and teacher to ask questions as they arose." ${ }^{106}$ More surprising was Miller's candid description of outright censoring:

There was some difficulty with a very few students who tired quickly and marked their answer sheets at random, making some unusual pictures or number designs. These few were excluded from the total tabulation as invalid. A few pupils gave "wise" and "curt" answers on the fact sheet to questions that they may have thought personal or irrelevant, but these were reviewed and corrected before leaving the school. ${ }^{117}$

It is not entirely clear that any of the interventions affected the Iowa Tests of Basic Skills, which were the basis for Hostetler's claim of Amish educational equivalence. Several other tests measuring aptitude and personality traits were also administered. ${ }^{108}$ But at the very least, Miller's observations reveal more than a mere inclination to root for the Amish. Even after selecting schools in a way that favored the Amish, Hostetler's team was willing to censor responses that would have made Amish schools look bad.

Table 1 contains the number of schools and children tested, some demographics of the children and their families, and the selected Iowa Test results for each group of schools. Table 1 reports all of the information about the eighth-grade tests that Hostetler and Miller published, but Hostetler added some discussion of tests in younger grades (not reported in Table 1), which did nothing to change his conclusions." ${ }^{110}$

\footnotetext{
105 See Hostetler, Educational Achievement at 165 (cited in note 95).

106 Miller, Amish Academic Achievement at 112 (cited in note 55).

107 Id at 114 (emphasis added).

108 See Hostetler, Educational Achievement at 186, 189-240 (cited in note 95).

109 See id at $172 \&$ table 7.
} 
TABle 1. SAMPLE Characteristics AND IOWA TEST SCORES AMISH PRIVATE ONE-ROOM SCHOOLS AND PUBlic SCHOOLS

\begin{tabular}{|c|c|c|c|c|c|}
\hline \multirow[b]{3}{*}{$\begin{array}{l}\text { Number of } \\
\text { schools } \\
\text { Eighth } \\
\text { graders } \\
\text { tested }\end{array}$} & $\begin{array}{c}\text { (1) } \\
\text { Private }\end{array}$ & $\begin{array}{c}\text { (2) } \\
\text { Public }\end{array}$ & $\begin{array}{l}\text { (3) } \\
\text { Public }\end{array}$ & $\begin{array}{c}\text { (4) } \\
\text { Public }\end{array}$ & $\begin{array}{c}\text { (5) } \\
\text { Public }\end{array}$ \\
\hline & $\begin{array}{c}\text { One-Room } \\
\text { Amish }\end{array}$ & All Amish & Amish Half & $\begin{array}{c}\text { Non-Amish } \\
\text { Half }\end{array}$ & $\begin{array}{l}\text { All Non- } \\
\text { Amish }\end{array}$ \\
\hline & 14 & 2 & $3^{*}$ & $3^{*}$ & 1 \\
\hline $\begin{array}{l}\text { Eighth } \\
\text { graders } \\
\text { per school }\end{array}$ & 4.36 & 14 & 8.67 & 11.33 & 27 \\
\hline $\begin{array}{l}\text { Children } \\
\text { per family } \\
\text { Time in } \\
\text { same }\end{array}$ & 8.5 & 7.6 & 7.3 & 4.2 & 4.3 \\
\hline $\begin{array}{c}\text { home } \\
\text { Walk to } \\
\text { school }\end{array}$ & $11.5 \mathrm{yrs}$ & $13.5 \mathrm{yrs}$ & $10.5 \mathrm{yrs}$ & $7.1 \mathrm{yrs}$ & $6.5 \mathrm{yrs}$ \\
\hline \multirow[t]{2}{*}{$\begin{array}{l}\text { Family } \\
\text { farmers }\end{array}$} & $75 \%$ & $63 \%$ & $58 \%$ & $9 \%$ & $30 \%$ \\
\hline & \multicolumn{5}{|c|}{ Iowa Test Scores Relative to National Mean, in Years.Months } \\
\hline \multicolumn{5}{|l|}{ Arithmetic } & -0.19 \\
\hline Word usage & 0.64 & -0.37 & -0.37 & -1.22 & -1.90 \\
\hline Spelling & 0.51 & 0.09 & 0.28 & -1.16 & -0.83 \\
\hline \multicolumn{6}{|l|}{ Reference } \\
\hline use & -1.00 & -0.34 & -0.74 & -0.95 & -0.55 \\
\hline Reading & -1.20 & -1.34 & -1.20 & -1.23 & -1.14 \\
\hline $\begin{array}{l}\text { Vocabulary } \\
\text { Source: Hostetle } \\
\text { Achievement at } 1 \\
\text { " There are three } \\
\text { half" schools are } \\
\text { as "mixed" schoo }\end{array}$ & $\begin{array}{l}\quad-1.61 \\
\text { Educational } A c \\
4-48 \text { (cited in not } \\
\text { not six, schools } \mathrm{i} \\
\text { pproximations of } \\
\text { s. }\end{array}$ & $\begin{array}{l}-1.86 \\
\text { ment at } 51-5 \\
\text { umns (3) and } \\
\text { roportions in }\end{array}$ & $\begin{array}{l}-2.23 \\
170 \text { (cited in no } \\
\text { ) combined. Publ } \\
\text { three schools tha }\end{array}$ & $\begin{array}{c}-1.09 \\
\text { e 95); Miller, } A m \\
\text { c "Amish half" an } \\
\text { Hostetler and Mil }\end{array}$ & $\begin{array}{r}-0.70 \\
\text { sh Academic } \\
\text { “non-Amish } \\
\text { er designated }\end{array}$ \\
\hline $\begin{array}{l}\text { The } \\
\text { smallest e } \\
\text { the public } \\
\text { graders. I } \\
\text { some Am }\end{array}$ & $\begin{array}{l}\text { rteen An } \\
\text { th-grade } \\
\text { hool that } \\
\text { possible } \\
\text { pupils ( }\end{array}$ & $\begin{array}{l}\text { one-ro } \\
\text { lorts, abo } \\
\text { no Ami } \\
\text { at the five }\end{array}$ & $\begin{array}{l}n \text { schools } \\
t \text { four in e } \\
\text { (column } 5 \\
\text { public sche }\end{array}$ & $\begin{array}{l}\text { column 1) } \\
\text { ch. The lar } \\
\text {, had only } \\
\text { ols that hac }\end{array}$ & $\begin{array}{l}\text { had the } \\
\text { est unit, } \\
7 \text { eighth } \\
\text { at least }\end{array}$ \\
\hline
\end{tabular}


seventh and eighth), since their average class size is small, but it is clear from the low percentage of pupils who walked to school that these were consolidated elementary schools of the sort that the Amish were said to want to avoid. (This raises the question of why Amish children were attending such schools, but later authors have indicated that many rural public schools, especially in Ohio and Indiana, strive to accommodate the Amish in their jurisdictions. $)^{110}$

The clearest demographic differences between the Amish (columns 1-3) and the non-Amish (columns 4-5) are the Amish's larger family size, lower mobility (as judged by years in same home), and larger percentage of families who are farmers. The test scores themselves are arrayed (in this Article's Table 1) in the order of those in which the eighth graders in the Amish one-room schools did best. The scores were reported as deviations from a national gradeequivalent mean for Iowa Tests, to be read in years (to the left of the decimal) and months (after the decimal point) above or below the average. ${ }^{.11}$ (I take the second digit after the decimal point as tenths of a month.) Thus the eighth graders in the Amish one-room school (column 1) had a score of 1.06 for arithmetic problem solving, which is one year and six-tenths of a month above the national grade norm.

Both Miller and Hostetler report the results of an analysis of variances between the groups of eighth graders in each of the columns. Thus, for example, Miller finds that the mean "arithmetic problem solving" score for the sixty-one Amish one-room students (column 1 in Table 1 above) is significantly higher than that of the thirty-four non-Amish students in the three mixed public schools (column 4).12 These comparisons are misleading. The relevant issue is the quality of Amish one-room schools versus public consolidated schools, not Amish students versus non-Amish students. The number of observations for that purpose is fourteen one-room schools and six public schools. Counting each of the eighth graders as a relevant observation in a statistical sample makes the sample look artificially large. One needs enough student scores to reliably infer something about each type of school (something achievable for the one-room schools only by grouping them), but confidence in the differences in school averages does not add to the number of schools compared. The more important sample here is not the students but the twenty

110 See Hurst and McConnell, Amish Paradox at 156 (cited in note 7).

111 Hostetler, Educational Achievement at 170 (cited in note 95).

112 See Miller, Amish Academic Achievement at 134-35 table 13 (cited in note 55). See also Hostetler, Educational Achievement at 318 table A-14 (cited in note 95). 
schools, and this is far too small a sample to make confident generalizations, even if the sample had been randomly chosen.

The most logical test of this small sample would be to compare the Iowa Test scores of the 61 children in the Amish one-room schools to those of the 115 children in the six public schools. ${ }^{113}$ On this basis the fourteen Amish one-room schools come out looking a little better than the six public schools. The public-school eighth graders performed slightly better in the tests on vocabulary and use of reference materials, while the Amish one-room scholars performed distinctly better in arithmetic problem solving, word usage, and spelling. Reading comprehension was about the same for both groups. It is notable that students in all of these schools are below the national grade average in most of the areas tested, though it is conceivable that this shortcoming characterized small rural schools generally in the late 1960 s. In any case, it should be evident from my discussion of sample bias, tendentious testing procedures, and the meager number of schools to be compared that any generalizations based on this study should have been made with many qualifications.

The other major problem with Hostetler's study was its exclusion of academic subjects to be tested. The Iowa Tests of Basic Skills were widely used by schools inside and outside Iowa as a diagnostic tool. ${ }^{14}$ For the eighth graders in Hostetler's study, the Iowa Tests were given for "vocabulary, reading comprehension, spelling, word usage, knowledge and use of reference materials, and arithmetic problem solving.",15

This sounds reasonably comprehensive, but it actually represented only about half of the Iowa Test battery. Not administered were the tests for "capitalization, punctuation, map reading, reading graphs and tables, and arithmetic concepts."116 Hostetler excluded these because the Amish did not study them with the same intensity as the other areas. ${ }^{117}$ This makes the high Amish scores in arithmetic (the area in which they scored unambiguously better than non-Amish) less impressive. "Arithmetic problem solving," which the Amish were good at, is different from

113 Hostetler also compared Amish students in all types of schools (columns 1-3 in Table 1) to non-Amish in all schools (columns 4 and 5), see Hostetler, Educational Achievement at 235-40 (cited in note 95), but this comparison confounds the issue of school quality with the characteristics of the students.

114 See id at $47-48$.

115 Miller, Amish Academic Achievement at 112 (cited in note 55).

116 Id.

117 Hostetler and Huntington, Children in Amish Society at 90 (cited in note 9). 
"arithmetic concepts," which were not tested. But the latter skill is most useful for doing any further work in mathematics. ${ }^{118}$ Nor were other Iowa Tests of quantitative skills, such as interpreting graphs and tables, included in Hostetler's customized battery.

There was another Amish advantage of using the Iowa Tests as they were then constituted. The Iowa Tests did not test all of the subjects that are normally taught in elementary schools. They did not test social studies, science, history, or geography. Teachers in Amish one-room schools spend much less time on these subjects because they have so many grade-levels to teach. The critical but unstated advantage that this confers on the Amish one-room school is that most of the students' normal school time is spent on the subjects that Hostetler selected for testing. Thus, the drawback of the one-room school - the single teacher having to manage many short recitation sessions-is offset by having the tests exclude the subjects she has does not have time, parental permission, or personal knowledge to teach.

The comparison of Amish one-room schools to public schools thus appears as if both Amish (in one-room schools) and publicschool students spent the same fraction of their time on each subject. But the public-school kids also had to study history, social studies, world geography, modern science, mathematical concepts, physical education, art, and music. The more extensive curriculum of the public schools meant that their students devoted proportionately less time to the subjects in which both they and the Amish private school students were tested. Amish one-room-school students thus had an advantage in taking tests that were keyed exclusively to subjects they studied. Figuratively speaking, public-school kids were training for the decathlon, while the Amish one-room-school kids trained for the pentathlon (which I take here to mean half of the decathlon events), and it was only the pentathlon events in which both competed. ${ }^{119}$

118 For example, compare doing division with the concept of things being divisible. The first can be done perfectly by rote memorization, but the second allows a person to take the idea of division and apply it in other circumstances.

119 In an email of March 15, 2011 (on file with the author), Trudy Huntington, Hostetler's coauthor, who was then with the University of Michigan, explained that:

[b]ecause we were interested (at least I was) in whether it was possible for Amish to successfully teach their own children, I felt it was only fair to test those subjects that were actually being taught. As is evident there was no interest among the Amish in preparing children for higher education. The comparison with rural public schools was to evaluate results in those areas of education that the Amish deemed important - not to compare the total educational preparation for higher education or for life off the farm. In those educational areas that the Amish considered important, the Amish and the public schools proved to be comparable. 
There are some other biases in the testing that favored the Amish. Amish children often did not enter first grade until they turned age seven, and so their eighth graders were on average older than those in the non-Amish comparison groups. ${ }^{120}$ If modern studies can be applied to the 1960 s, children who enter first grade at an older age have a considerable academic advantage in school. ${ }^{121}$ As indicated in Table 1, Amish families stay in their homes (and presumably the same schools) about 50 percent longer than nonAmish families. Again, modern research has found that frequently changing schools is detrimental to children's learning. ${ }^{12}$

But these last two are minor issues compared to Hostetler's powerfully biased selection of schools and academic subjects to be tested. His results do not support the claim that "[a]s judged by education testing standards the overall performance of the Amish is similar to that of a representative sample of rural school children in the United States." ${ }^{23}$ The educational testing was selected to cover only the subjects taught intensively in Amish one-room schools; the test administrators censored unwanted results; the sample was tiny, irreproducible, and selected to get the better one-room schools; and the geographic area was not "the United States" but a few vaguely identified areas of the Midwest.

\section{CONCLUSION: IS YODER STILL GOOD FOR THE AMISH?}

Yoder did not entirely exempt the Amish from state regulations concerning school attendance. It instead commended programs like the Pennsylvania post-eighth-grade vocational plan, which involved two years of home-based training in which formal classroom work was three hours a week. ${ }^{124}$ The critical post-Yoder difference from these previously negotiated compromises is that state educators now know that the Amish have a powerful fallback position if officials were to press for more formal education. Even though the Amish are reluctant to litigate, the Yoder decision could make states leery of pressing the Amish beyond any educational standards mentioned in

Email from Gertrude Huntington, former professor, University of Michigan, to William Fischel, Professor of Economics, Dartmouth College (Mar 15, 2011) (on file with author).

120 Hostetler, Educational Achievement at 166 (cited in note 95).

121 Elizabeth Cascio and Diane Whitmore Schanzenbach, First in the Class? Age and the Education Production Function *1 (NBER Working Paper No 13663, Dec 2007), online at http://www.nber.org/papers/w13663 (visited Oct 25, 2011).

122 See Eric A. Hanushek, John F. Kain, and Steven G. Rivkin, Disruption versus Tiebout Improvement: The Costs and Benefits of Switching Schools, $88 \mathrm{~J}$ Pub Econ 1721, 1743-44 (2004).

123 Hostetler and Huntington, Children in Amish Society at 96 (cited in note 9).

124 Yoder, 406 US at $236 \&$ n 23. 
the Court's opinion. My guess is that many state officials are grateful not to have to play the bad cop in negotiating with the Amish. Even some previously accepted programs of post-elementary education have fallen away. ${ }^{125}$

I would not dispute that eight years of one-room schooling was adequate for the vision of Amish life as it existed for the first twothirds of the twentieth century, when most Amish were farmers and horse-powered agriculture was still economically viable. But twentyfirst-century Amish are having to adapt to an economy in which they must deal with technologically sophisticated employers, suppliers, and customers. ${ }^{26}$ The Amish are resourceful and hardworking, but it may someday occur to them that the eighth-grade ceiling on their formal education needs to be reexamined. If this is the case, Yoder may not be so Amish friendly. Although he was not concerned about their lack of formal education, Donald Kraybill, Hostetler's successor as the leading scholar on Amish affairs, declared in an interview that a (hypothetical) Amish attempt to establish vocational high schools "would certainly undermine the legal decision of the US Supreme Court in Wisconsin v. Yoder."

The Yoder decision itself was extraordinarily specific to the Amish and their agrarian way of life. ${ }^{128}$ Later Supreme Court decisions have further narrowed its precedential value, as William Ball, the lawyer for the Amish, lamented in later writings. ${ }^{129}$ Although the Amish are still protected by Yoder, the protection is based not on religious liberty considerations but on parental rights, which Ball regarded as peripheral to the case. ${ }^{130}$ Given this narrow legal platform, the Amish and their sympathizers might reasonably fear that increments to formal education beyond the eighth grade or a more comprehensive elementary program could undermine Amish self-determination in educational matters. What was once a floor on Amish education now looks like a ceiling.

125 See Johnson-Weiner, Train Up a Child at 162 (cited in note 8).

126 See generally Donald B. Kraybill and Steven M. Nolt, Amish Enterprise: From Plows to Profits 3 (Johns Hopkins 2d ed 2004). It should be noted, however, that Donald Kraybill and Steven Nolt are optimistic about the ability of Amish entrepreneurs to succeed without attending high school. See id at 202.

127 Interview with Donald Kraybill (2008), online at http://www.amishamerica.com/anamish-america- $q$-and-a-with-professor-donald-kraybill (visited Oct 25, 2011).

128406 US at 235.

129 William B. Ball, First Amendment Issues, in Kraybill, ed, Amish and the State 253, 264 (cited in note 85). On William Ball's larger mission to promote public funding for Catholic parochial education, see Peters, Yoder Case at 64 (cited in note 58).

130 See Ball, First Amendment Issues at 264 (cited in note 129). 
I want to gingerly suggest that Yoder may no longer be as important in allowing the Amish to find their own educational paths. Even if they were to depart from its apparent eighth-grade ceiling on their education, it is unlikely that states would force them back into a system that necessarily culminates with high school. For one thing, there is widespread approval by the public of the Amish, who are now "viewed as a living part of America's heritage." 131 One manifestation of this is that many Amish settlements are objects of ethnic tourism. The Amish have not sought this attention, but most have grudgingly adapted to tourism, and a growing number profit from the additional demand for their locally made crafts and prepared foods. ${ }^{132}$

More important is that tourism enhances the value of an Amish community to others in the regions where they are concentrated. Kraybill concludes after an extended and somewhat ambivalent discussion of tourism that "the economic value of the Amish as a tourist attraction has greatly enhanced their bargaining power with public officials." rather than exercise political or legal "voice," to use terms made famous by Albert Hirschman. ${ }^{134}$ Historically, the Amish have preferred to emigrate from unfriendly jurisdictions rather than become entangled in political institutions, and this persists to the present. A group left Nebraska in the early 1980s over a dispute with the state about teacher certification and milk processing standards, declining the offer of legal counsel by Ball, the successful Yoder attorney. ${ }^{135}$

Another reason for the decline in the importance of Yoder is the rise of the homeschool movement. Despite the limiting language of Chief Justice Burger's opinion, non-Amish families who wanted to homeschool their children rather than send them to public or approved private schools were inspired by the notion that parental rights could trump compulsory education statutes. ${ }^{136}$ Even though no court case has specifically extended Yoder's protections to

131 Peter V. Schaeffer, Outline of an Economic Theory of Assimilation, $36 \mathrm{~J}$ Regional Analysis \& Pol 153, 158 (2006). The Amish were not formerly so well regarded. See Hostetler, Amish Society at 397 (cited in note 14).

132 See Kraybill, Riddle of Amish Culture at 292 (cited in note 17).

133 Id at 293.

134 Albert O. Hirschman, Exit, Voice and Loyalty: Responses to Decline in Firms, Organizations, and States 23, 35 (Harvard 1970).

135 Dewalt, Amish Education at 42 (cited in note 29).

136 See Peters, Yoder Case at 174 (cited in note 58); Martha Minow, Keynote: Before and after Pierce; A Colloquium on Parents, Children, Religion and Schools, 78 U Detroit Mercy L Rev 407, 417 (2001). 
homeschoolers, the movement has grown spectacularly since $1970 .^{137}$ Homeschool organizations have instead used political action to change state laws about attendance, curriculum, and teacher qualifications that stood in their way. Among the states that now have highly liberalized homeschooling statutes is Wisconsin, whose formerly rigid school laws started the controversy in Yoder. ${ }^{138}$ The political clout of homeschoolers provides an umbrella that shields the Amish, too. ${ }^{139}$

I close with a reminder of my original mission. I wanted to show that one-room school education is not an adequate substitute for multiroom elementary schools for children who expect to go to high school. The early twentieth-century high school movement caused the consolidation of the tens of thousands of one-room school districts. The voters who accepted this did so for a good reason, not because bureaucrats forced it on them. One-room schools could not reliably stream children into secondary education. The Amish cling to them for that very reason.

137 Compare Patricia M. Lines, Homeschoolers: Estimating Numbers and Growth 1 (Office of Educational Research and Improvement, Department of Education Spring 1999), online at http://www2.ed.gov/offices/OERI/SAI/homeschool/homeschoolers.pdf (visited Oct 25 , 2011) (stating that estimates suggest that between 10,000 and 15,000 children were homeschooled in the late 1970s), with Stacey Bielick, Kathryn Chandler, and Stephen P. Broughman, Homeschooling in the United States: 19994 table 1 (Office of Educational Research and Improvement, Department of Education July 2001), online at http://nces.ed.gov/pubs2001/2001033.pdf (visited Oct 25, 2011) (estimating the number of homeschooled children at 850,000 in 1999).

138 See Robin L. West, The Harms of Homeschooling, 29 Phil \& Pub Pol Q 7, 11 (2009).

139 Traditional Amish, however, usually disdain homeschooling because it does not promote the group socialization that their one-room schools foster. See Hurst and McConnell, Amish Paradox at 162 (cited in note 7) (describing the reactions of many Old Order Amish to homeschoolers and noting that they see them as "dissenters" who are not fully engaged in the community). 


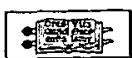

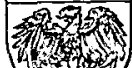

